University of Nebraska - Lincoln

DigitalCommons@University of Nebraska - Lincoln

\title{
Frequency of Luteinizing Hormone Pulses in Cattle Influences Duration of Persistence of Dominant Ovarian Follicles, Follicular Fluid Concentrations of Steroids, and Activity of Insulin-Like Growth Factor Binding Proteins
}

\author{
F. N. Kojima \\ University of Missouri \\ E. G. M. Bergfeld \\ American Society of Animal Science, ebergfeld@sciencesocieties.org \\ M. E. Wehrman \\ Rocky Mountain Reproductive Services Inc.
}

A. S. Cupp

University of Nebraska-Lincoln, acupp2@unl.edu

K. E. Fike

Ohio State University, karol@ksu.edu

See next page for additional authors
Follow this and additional works at: https://digitalcommons.unl.edu/hruskareports

\footnotetext{
Kojima, F. N.; Bergfeld, E. G. M.; Wehrman, M. E.; Cupp, A. S.; Fike, K. E.; Mariscal-Aguayo, D. V.; SanchezTorres, T.; Garcia-Winder, M.; Clopton, D. T.; Roberts, A. J.; and Kinder, J. E., "Frequency of Luteinizing Hormone Pulses in Cattle Influences Duration of Persistence of Dominant Ovarian Follicles, Follicular Fluid Concentrations of Steroids, and Activity of Insulin-Like Growth Factor Binding Proteins" (2003). Roman L. Hruska U.S. Meat Animal Research Center. 242. https://digitalcommons.unl.edu/hruskareports/242
}

This Article is brought to you for free and open access by the U.S. Department of Agriculture: Agricultural Research Service, Lincoln, Nebraska at DigitalCommons@University of Nebraska - Lincoln. It has been accepted for inclusion in Roman L. Hruska U.S. Meat Animal Research Center by an authorized administrator of DigitalCommons@University of Nebraska - Lincoln. 


\section{Authors}

F. N. Kojima, E. G. M. Bergfeld, M. E. Wehrman, A. S. Cupp, K. E. Fike, D. V. Mariscal-Aguayo, T. SanchezTorres, M. Garcia-Winder, D. T. Clopton, A. J. Roberts, and J. E. Kinder 
Frequency of luteinizing hormone pulses in cattle influences duration of persistence of dominant ovarian follicles, follicular fluid concentrations of steroids, and activity of insulin-like growth factor binding proteins ${ }^{\text {th }}$

\author{
F.N. Kojima ${ }^{\text {a, } 1}$, E.G.M. Bergfeld ${ }^{\text {a, } 2}$, M.E. Wehrman ${ }^{\text {a,3 }}$, A.S. Cupp ${ }^{\text {a }}$, \\ K.E. Fike ${ }^{\mathrm{a}, 4}$, D.V. Mariscal-Aguayo ${ }^{\text {a, } 5}$, T. Sanchez-Torres ${ }^{\text {a, }}{ }^{\text {, }}$, \\ M. Garcia-Winder ${ }^{\mathrm{a}, 7}$, D.T. Clopton ${ }^{\mathrm{a}}$, A.J. Roberts ${ }^{\mathrm{b}}$, J.E. Kinder ${ }^{\mathrm{a}, *}$ \\ a Department of Animal Science, University of Nebraska, Lincoln, NE 68583-0908, USA \\ b The US Department of Agriculture, Agricultural Research Service, Roman L. Hruska, US Meat Animal \\ Research Center, Clay Center, NE 68933-0166, USA
}

Received 11 June 2002; received in revised form 3 January 2003; accepted 24 January 2003

\begin{abstract}
The objectives of the present study were to determine how varying frequency of LH pulses as controlled by varying treatments with progesterone $\left(\mathrm{P}_{4}\right)$ in cattle would affect: $(1)$ concentration of steroid hormones and activity of insulin-like growth factor binding proteins (IGFBPs) in the ovarian follicular fluid and blood plasma, and (2) duration of persistence of largest ovarian follicles. There
\end{abstract}

\footnotetext{
¿ Published as paper no. 12594, Journal Ser. Nebraska Agr. Res. Div.; Research supported by USDA NRI 90-37240-5714. The mention of trade names is necessary to report factually on available data; however, the USDA neither guarantees nor warrants the standard of the product, and the use of the name by the USDA implies no approval of the product to the exclusion of others that may also be suitable.

* Corresponding author. Present address: Department of Animal Sciences, The Ohio State University, 110 Animal Science Building, 2029 Fyffe Rd., Columbus, OH 43210-1095, USA. Tel.: +1-614-292-3232; fax: + 1-614-292-2929.

E-mail address: kinder.15@osu.edu (J.E. Kinder).

1 Department of Animal Sciences, University of Missouri, Columbia, MO 65211, USA.

2 American Society of Animal Science, 1111 N. Dunlap Ave. Savoy, IL 61874, USA.

3 Rocky Mountain Reproductive Services Inc., P.O. Box 299, Manhattan, MT 59741, USA.

4 Department of Animal Sciences, The Ohio State University, Columbus, OH 43210-1095, USA.

5 Departmento de Zootecnia, Universidad Autonoma Chapingo, Chapingo Edo 56320, Mexico.

6 Programa de Ganaderia, Colegio de Postgraduados, Montecillos Edo 56320, Mexico.

${ }^{7}$ International Marketing, T.C. Jacoby, St. Louis, MO 63127, USA.
} 
were four treatment groups ( $n=7$ per group) and a control group $(n=5)$ of mature, non-lactating beef cows. Treatments were: (1) two progesterone releasing intravaginal devices (PRIDs) for 16 days (2PRID); (2) a half PRID for 16 days (0.5PRID); (3) two PRIDs for 8 days, then a half PRID for 8 days (2-0.5PRID); or (4) a half PRID for 8 days, then two PRIDs for 8 days (0.5-2PRID). Treatment was initiated on the fifth day of the estrous cycle, which was designated as Day 0 , and continued for 16 days. All $\mathrm{P}_{4}$-treated females were administered prostaglandin $\mathrm{F}_{2 \alpha}$ on Day 0 and 1 to regress their corpora lutea. Frequency of LH pulses was greater during treatment with the smaller dose of $\mathrm{P}_{4}$ compared with treatment with the larger dose of $\mathrm{P}_{4}$ and the control group. Ovarian follicles were classified into five categories based on ultrasonographic observations: growing $(\mathrm{G})$; atretic (A); growing dominant (GD); growing persistent (GP); or atretic persistent (AP). At ovariectomy on Day 16, the largest and second largest follicles collected were re-classified into five categories based on follicular concentration of steroids. Classification of the largest follicle collected on Day 16 was influenced by treatment $(P<0.005)$, with the 2PRID group having A follicles, the 2-0.5PRID group GP follicles, the 0.5-2PRID group AP follicles, and the 0.5PRID group GD and GP follicles. Concentrations of $17 \beta$-estradiol $\left(\mathrm{E}_{2}\right)$ were greatest in GD and GP follicles $(P<0.05)$. There was less $(P<0.05)$ activity of IGFBP-2 in GD follicles and less $(P<0.05)$ activity of IGFBP-3 in GD and GP follicles than other follicles. Activity of IGFBP-4 and -5 was greater $(P<0.05)$ in A and AP follicles than G, GD, and GP follicles. Maintenance of a frequent release of LH pulses over a 16-day period did not result in maintenance of persistent follicles throughout this period indicating that duration of dominance of these follicles is finite even when there is frequent release of LH pulses. Follicular atresia is associated with greater activity of IGFBP-2, $-4,-5$, and greater concentrations of $\mathrm{P}_{4}$ in follicles, whereas growing dominant and persistent follicles contained greater concentrations of $\mathrm{E}_{2}$, androstenedione $\left(\mathrm{A}_{4}\right)$, and less IGFBP-2 activity than follicles of other classes. Follicle classifications based on ultrasonography or follicular concentration of steroids did differ $(P<0.05)$ for the largest follicles from the 2PRID group. Two follicles in this group appeared as GD follicles by ultrasonography, but these were atretic based on follicular steroid contents. Objective 1 of the present study yielded the conclusion that concentrations of steroid hormones in follicular fluid and blood plasma could be predictably controlled by regulating the frequency of $\mathrm{LH}$ pulses with varying doses of $\mathrm{P}_{4}$. Objective 2 yielded the conclusion that maintain frequent release of LH pulses over a 16-day period could not maintain persistent follicles throughout this period, indicating that duration of dominance of these follicles is finite even when there is frequent release of LH pulses. Follicular atresia in the present study was associated with increased follicular fluid activity of IGFBP-2, $-4,-5$, and $\mathrm{P}_{4}$, whereas growing dominant and persistent follicles contained greater concentrations of $\mathrm{E}_{2}, \mathrm{~A}_{4}$, and less IGFBP-2 activity than follicles of other classes. (C) 2003 Elsevier Science B.V. All rights reserved.

Keywords: Progesterone; LH; Ovarian follicles; IGF-binding proteins; Cattle-endocrinology

\section{Introduction}

Treatment of cattle with amounts of progesterone $\left(\mathrm{P}_{4}\right)$ used commercially $(1-2 \mathrm{ng} / \mathrm{ml}$ of plasma) for synchronization of estrus, or synthetic progestins in the absence of the corpus luteum, prolongs the duration of dominance of the largest follicle. This follicle has been described as a persistent dominant follicle (Sirois and Fortune, 1990; Cupp et al., 1992; Stock and Fortune, 1993; Taylor et al., 1993). Persistence of a follicle results from greater frequency of LH pulses, which in turn are due to prolonged presence of progestin concentrations in blood that are less than those during the mid-luteal phase of the estrous cycle. 
Persistent follicles secrete greater amounts of $17 \beta$-estradiol $\left(E_{2}\right)$ than typical dominant follicles present during the luteal phase of the estrous cycle; concentrations of $\mathrm{E}_{2}$ in blood, however, are similar to those during the follicular phase of the estrous cycle (Cupp et al., 1992; Roberson et al., 1989; Kojima et al., 1992). Inseminations associated with ovulation from persistent follicles result in lesser pregnancy rates than ovulations from typical dominant follicles (Stock and Fortune, 1993; Savio et al., 1992; Sanchez et al., 1993; Wehrman et al., 1993). Differences likely exist in biochemical characteristics of this type of follicle when compared with follicles exhibiting a typical life span (Manikkam and Rajamahendran, 1997; Bigelow and Fortune, 1998).

Accumulating evidence suggests the involvement of growth factors, such as insulin-like growth factor-I (IGF-I), in the local regulation of follicular development (Erickson and Danforth, 1995; Hillier, 1994). There is stimulation by IGF-I and FSH to induce proliferation of granulosal cells and enhance steroidogenesis in these cells (Manikkam and Rajamahendran, 1997; Adashi et al., 1991; Hammond et al., 1991; Giudice, 1992; Spicer and Echternkamp, 1995). Greater concentrations of IGF-I are associated with greater concentrations of $\mathrm{E}_{2}$ in follicular fluid and increased diameter of follicles (Echternkamp et al., 1994). While differences in intra-follicular amounts of IGF-I may exist, intra-follicular IGF-binding proteins (IGFBPs) likely regulate bioavailability of IGF-I in follicles (Manikkam and Rajamahendran, 1997; Ui et al., 1989).

Objectives of the study were to determine influence of frequency of LH pulses as influenced by administering different doses of $\mathrm{P}_{4}$ on concentration of steroid hormones and activity of IGFBPs in follicular fluid and blood plasma, and duration of persistence of largest follicles.

\section{Materials and methods}

\subsection{Experimental protocol}

All procedures used in this experiment were approved by the Institutional Animal Care and Use Committee at the University of Nebraska. Mature non-lactating premiparous and multiparous beef cattle $(4.6 \pm 0.6$ years old and $441 \pm 2 \mathrm{~kg})$ of a composite breed type (MARC III: 1/4 Hereford, 1/4 Angus, 1/4 Pinzgauer, 1/4 Red Poll) exhibiting estrous cycles of typical duration were used in this study. Stage of the estrous cycle was synchronized in all females before initiation of treatments by administration of two injections of prostaglandin $\mathrm{F}_{2 \alpha}\left(\mathrm{PGF}_{2 \alpha} ; 25 \mathrm{mg} ;\right.$ Lutalyse $^{\circledR}$ Sterile Solution; Pharmacia Animal Health, Kalamazoo, MI) 11 days apart. Females $(n=33)$ exhibiting behavioral estrus synchronously were randomly assigned to one of four treatment groups or an untreated control group. Treatments were initiated on the fifth day of the estrous cycle, which was designated as Day 0 of treatment, and continued for 16 days. Treatments used to modulate frequency of LH pulses that resulted in different types of follicle growth were: (1) two $\mathrm{P}_{4}$ releasing intravaginal devices (PRIDs: Sanofi Animal Health Inc., Paris, France) resulting in 5-9 ng/ml plasma $\mathrm{P}_{4}$ (2PRID); (2) a half PRID resulting in 1-3 ng/ml plasma $\mathrm{P}_{4}$ (0.5PRID); (3) two PRIDs for 8 days and a half PRID the next 8 days (2-0.5PRID); and (4) a half PRID for 8 days and two PRIDs for the next 8 days (0.5-2PRID; $n=7$ /group). One PRID was cut into two halves to produced half PRIDs 
(0.5PRID). Females administered $\mathrm{P}_{4}$ were treated with $\mathrm{PGF}_{2 \alpha}$ to regress their corpora lutea on Days 0 and 1 of treatment and were ovariectomized at the end of treatment. Five animals served as untreated controls that were not ovariectomized at the end of treatment. Control females were allowed to progress through their estrous cycle until ovulation during the next estrous cycle was confirmed. For the treatment groups which received two PRIDs (2PRID, 2-0.5PRID, and 0.5-2PRID), the two PRIDs were inserted over a 2-day period to avoid a large bolus release of $\mathrm{P}_{4}$ into blood and replaced every 4 days to maintain concentrations of $\mathrm{P}_{4}$ in blood plasma similar to those of the mid-luteal phase of the estrous cycle. For instance, PRIDs were inserted on Days 0 and 1 (2PRID and 2-0.5PRID) or Days 8 and 9 (0.5-2PRID) and replace on Days 4 and 5 (2PRID and 2-0.5PRID), 8 and 9 (2PRID), and 12 and 13 (2PRID and 0.5-2PRID). For females of the 0.5-2PRID and 0.5PRID groups, a half PRID was inserted on Day 0. The half PRIDs, which were removed on Day 8 from females of the 0.5-2PRID group, were inserted into females of 2-0.5PRID group on the same day to avoid a bolus release of $\mathrm{P}_{4}$ in blood.

Length of $\mathrm{P}_{4}$ treatment periods (i.e. 8 days) was designed to allow for changes in follicular development to occur during the treatment period based on previous studies (Roberson et al., 1989; Kojima et al., 1992), where length of a typical follicular phase in cattle averaged about $72 \mathrm{~h}$ (3 days). Duration of the growth phase of dominant follicles in cattle with either two or three waves of follicular development ranged from 3.4 to 7.5 days (Savio et al., 1988; Sirois and Fortune, 1988). Therefore, a period approximately 2.5 times longer than a typical follicular phase, or longer than the typical duration of growth of dominant follicles during the estrous cycle, was considered to be of sufficient duration to allow for alterations in follicular development during the $\mathrm{P}_{4}$ treatments.

Indwelling jugular cannulae were fitted in each animal on Day 5 of treatment. Blood samples were collected on Days 7, 12, and 16 for $12 \mathrm{~h}$ at $15 \mathrm{~min}$ intervals to characterize LH pulses. Samples collected were allowed to clot at room temperature and then stored at $4{ }^{\circ} \mathrm{C}$ for $24 \mathrm{~h}$. Samples were centrifuged at $1520 \times g$ for $15 \mathrm{~min}$, and serum was decanted and stored at $-20^{\circ} \mathrm{C}$ until assayed for LH. Daily blood samples were collected in tubes containing a $30 \%$ solution of EDTA $(50 \mu \mathrm{l}$ for $10 \mathrm{ml}$ blood sample; Fisher Scientific Co., Fair Lawn, NJ) from all animals throughout the treatment period until ovariectomy or until ovulation (control females). Samples were placed on ice immediately and plasma was separated from blood cells by centrifugation at $1520 \times g$ for 20 min within $1 \mathrm{~h}$ of collection to reduce degradation of $\mathrm{P}_{4}$ in blood. Plasma was then harvested and stored at $-20{ }^{\circ} \mathrm{C}$ until assayed for $\mathrm{P}_{4}, \mathrm{E}_{2}$, and FSH.

\subsection{Ovarian follicle evaluations}

Changes in size of follicles were characterized by real-time linear ultrasonography conducted daily from Day 0 until ovariectomy in $\mathrm{P}_{4}$-treated groups (Day 16) or until ovulation in the control group. Ultrasonography was performed with an Equisonic LS300 Real-Time Linear Scanner equipped with a transrectal 7.5 MHz linear array transducer (Tokyo Keiki LS300A; Products Group International, Boulder, CO). Images of each ovary were recorded daily and follicles were measured by means of a built-in caliper system. Duration of detection was defined as the number of days when an individual follicle was evident via ultrasonography. Maximum diameter of a follicle was the largest diameter measured; growth rate of 
a follicle was defined as the maximum diameter minus diameter on day of initial detection divided by number of days of follicle growth. Dominant follicles were defined as the largest follicles increasing in or maintaining diameter in the ovary with other follicles regressing or regressed, while inhibiting emergence of a new wave of follicular development. Emergence of the new follicular wave indicated that the largest follicle lost its dominancy. Emergence of second and third waves of follicular development was defined as day of the treatment when a dominant follicle for the subsequent wave of follicular development appeared in the ovary. Ovariectomy was performed by colpotomy on Day 16. Immediately after removal, ovaries were transported to the laboratory on ice. The two largest follicles (F1 and F2) from ovaries of each cow were dissected, measured, frozen in liquid nitrogen and stored at $-80^{\circ} \mathrm{C}$ until further analysis of follicular fluid content of $\mathrm{E}_{2}, \mathrm{P}_{4}$, androstenedione $\left(\mathrm{A}_{4}\right)$, and IGFBPs.

\subsection{Follicle classification based on the ultrasonographic observation}

Largest and second largest follicles (F1 and F2) were classified into five classes based on pattern of growth or regression observed by ultrasonography during the treatment period (Table 1): (1) growing follicles (G: $n=9)$; (2) atretic follicles (A: $n=12)$; (3) growing dominant follicles (GD: $n=7$ ); (4) growing persistent follicles (GP: $n=10$ ); and (5) atretic persistent follicles (AP: $n=10$ ). Growing follicles $(\mathrm{G})$ were defined as F2 follicles increasing in size, but with a diameter of $<10 \mathrm{~mm}$. Atretic follicles (A) were defined as F1 follicles after emergence of the next follicular wave or F2 follicles decreasing in size. Growing dominant follicles (GD) were defined as F1 follicles that were largest follicles increasing in or maintaining diameter in the ovary with other follicles regressing or regressed, while inhibiting emergence of a new wave of follicular development with less than 10 days of detection by ultrasonography.

Table 1

Distribution of the largest (F1) and the second largest (F2) follicles present in the ovaries from each cow in the treatment groups by follicle classifications based on ultrasonographic observations

\begin{tabular}{|c|c|c|c|c|c|c|}
\hline \multirow[t]{2}{*}{ Treatment $^{\mathrm{a}}$} & \multicolumn{5}{|c|}{ Follicle classifications $^{\mathrm{a}}$} & \multirow[t]{2}{*}{ Total } \\
\hline & G & GD & GP & A & AP & \\
\hline \multicolumn{7}{|l|}{$\mathrm{F} 1$} \\
\hline 2PRID & - & 3 & - & 4 & - & 7 \\
\hline 2-0.5PRID & - & - & 7 & - & - & 7 \\
\hline 0.5-2PRID & - & - & - & - & 7 & 7 \\
\hline 0.5 PRID & - & 4 & 3 & - & - & 7 \\
\hline \multicolumn{7}{|l|}{$\mathrm{F} 2$} \\
\hline 2PRID & 3 & - & - & 3 & - & 6 \\
\hline 2-0.5PRID & - & - & - & - & - & 0 \\
\hline 0.5-2PRID & 5 & - & - & 2 & - & 7 \\
\hline 0.5 PRID & 1 & - & - & 3 & 3 & 7 \\
\hline Total & 9 & 7 & 10 & 12 & 10 & 48 \\
\hline
\end{tabular}

\footnotetext{
${ }^{\text {a }}$ See Section 2 for definition of abbreviations and explanations of follicle classifications and treatment regimens. Classification (growing (G), growing dominant (GD), growing persistent (GP), atretic (A), and atretic persistent (AP)) of the largest follicle by ultrasonographic observation was influenced by treatment $(P<0.05)$.
} 
Persistent follicles were defined as follicles larger than $10 \mathrm{~mm}$ in diameter with growth characteristics typical of persistent follicles as observed by ultrasonography. Growing persistent follicles (GP) were defined as largest follicles increasing in or maintaining diameter in the ovary with other follicles regressing or regressed, while inhibiting emergence of a new wave of follicular development with more than 10 days of detection by ultrasonography. Atretic persistent follicles (AP) were defined as persistent follicles (diameter $>10 \mathrm{~mm}$ and $>10$ days of detection by ultrasonography) being F1 follicles after emergence of the next follicular wave or F2 follicles decreasing in size. Duration of detection was, therefore, less $(P<0.05)$ in growing dominant follicles (mean \pm S.E.; $7.0 \pm 1.4$ days) than growing persistent follicles $\left(12.9 \pm 2.2\right.$ days). Treatment effects were tested by $\chi^{2}$ analysis using the CATMOD of SAS (1985) for the class of largest and second largest follicles collected from $\mathrm{P}_{4}$-treated groups on Day 16 (SAS, 1985).

\subsection{Follicle classification based on concentration of steroids}

Follicles (F1 and F2) classified based on ultrasonographic observation were re-classified into five classes based on follicular concentrations of $\mathrm{E}_{2}$ and $\mathrm{P}_{4}$, after those follicles were collected on Day 16 of treatment (Table 2). Largest (F1) follicles from two cows of the 2PRID group (one GD and one A follicles) and one cow of the 2-0.5PRID group (one GP follicle) were lost during collection. Two F1 follicles from the 2PRID group previously classified as growing dominant follicles based on the observation by ultrasonography were re-classified as atretic follicles based on follicular concentrations of $\mathrm{E}_{2}$ and $\mathrm{P}_{4}$. Two F2 follicles from the 2PRID group (one $\mathrm{G}$ and one A follicles) were lost during processing. For the second largest (F2) follicle classification in the 2-0.5PRID group, there was only

Table 2

Distribution of the largest (F1) and the second largest (F2) follicles present in the ovaries from each animal in the treatment groups by follicle classifications based on follicular concentration of steroid hormones

\begin{tabular}{|c|c|c|c|c|c|c|}
\hline \multirow[t]{2}{*}{ Treatment $^{\mathrm{a}}$} & \multicolumn{5}{|c|}{ Follicle classifications $^{\mathrm{a}}$} & \multirow[t]{2}{*}{ Total } \\
\hline & G & GD & GP & A & AP & \\
\hline \multicolumn{7}{|l|}{ F1 } \\
\hline 2PRID & - & - & - & 5 & - & $5^{\mathrm{b}}$ \\
\hline 2-0.5PRID & - & - & 6 & - & - & $6^{\mathrm{b}}$ \\
\hline 0.5 -2PRID & - & - & - & - & 7 & 7 \\
\hline 0.5 PRID & - & 4 & 3 & - & - & 7 \\
\hline \multicolumn{7}{|l|}{$\mathrm{F} 2$} \\
\hline 2PRID & 2 & - & - & 2 & - & $4^{b}$ \\
\hline 2-0.5PRID & - & - & - & - & - & $0^{\mathrm{b}}$ \\
\hline $0.5-2 \mathrm{PRID}$ & 5 & - & - & 2 & - & 7 \\
\hline 0.5 PRID & 1 & - & - & 3 & 3 & 7 \\
\hline Total & 8 & 4 & 9 & 12 & 10 & 43 \\
\hline
\end{tabular}

${ }^{a}$ See Section 2 for definition of abbreviations and explanations of follicle classifications and treatment regimens. Classification (growing (G), growing dominant (GD), growing persistent (GP), atretic (A), and atretic persistent (AP)) of the largest follicle collected on Day 16 was influenced by treatment $(P<0.05)$.

${ }^{\mathrm{b}}$ See Section 2.4 for explanation of follicle numbers in these categories. 
one follicle greater than $7 \mathrm{~mm}$; therefore, the F2 follicle from each cow was not analyzed for this group. Follicle classification based on follicular concentration of steroids resulted in: (1) growing follicles (G: $n=8)$; (2) atretic follicles (A: $n=12)$; (3) growing dominant follicles (GD: $n=4)$; (4) growing persistent follicles (GP: $n=9$ ); and (5) atretic persistent follicles (AP: $n=10$ ). Treatment effects were tested by $\chi^{2}$ analysis using the CATMOD of SAS (1985) for the class of largest and second largest follicles collected from $\mathrm{P}_{4}$-treated groups on Day 16 (SAS, 1985). Variables from growing follicles ( $G$ and GP) from different treatment groups and atretic follicles (A and AP) of F1 or F2 origin from different treatment groups were analyzed for treatment effects; and there was no treatment effect $(P>0.10)$ on follicular concentration of steroids or IGFBP activities. Follicles from all treatment groups were, therefore, pooled by follicle classifications to evaluate concentration of steroids and activity of IGFBPs in follicular fluid.

\subsection{Radioimmunoassays}

Concentrations of LH in samples collected serially were analyzed by RIA (Adams et al., 1975; Wolfe et al., 1989). Intra- and inter-assay coefficients of variation for LH assays were 3.1 and $7.8 \%$, respectively. Assay sensitivity was $30 \mathrm{pg} / \mathrm{ml}$. Concentrations of FSH in daily plasma samples were analyzed by RIA (Adams et al., 1975; Acosta et al., 1983). Intraand inter-assay coefficients of variation for FSH were 2.6 and $5.0 \%$, respectively. Assay sensitivity was $58 \mathrm{pg} / \mathrm{ml}$.

Concentrations of $\mathrm{P}_{4}$ in daily plasma samples were determined in non-extracted plasma using a RIA (Bergfeld et al., 1996). Volume of diluted (1:40) plasma samples used in these assays was $50 \mu \mathrm{l}$ per tube $(1.25 \mu \mathrm{l}$ plasma equivalent). Intra- and inter-assay coefficients of variation for $\mathrm{P}_{4}$ were 2.8 and $6.1 \%$, respectively. Assay sensitivity was $10 \mathrm{pg} / \mathrm{ml}$. Concentrations of $\mathrm{P}_{4}$ in follicular fluid samples were analyzed by RIA (Bergfeld et al., 1996). Validation of this assay for follicular fluid samples was performed as follows: samples of bovine follicular fluid were used to evaluate parallelism with the standard curve. Slopes of serial dilutions of pooled follicular fluid and a standard curve were not different $(P=0.707)$ as determined with the ALLFIT program (DeLean et al., 1978). Recovery of three different amounts of $\mathrm{P}_{4}(3.9,7.8$, and $15.6 \mathrm{pg})$ added to $50 \mu \mathrm{l}$ of diluted follicular fluid $(0.00625 \mu \mathrm{l}$ follicular fluid equivalent) averaged $95.5 \pm 7.4 \%$. Volumes of diluted follicular fluid samples used in the assays were $0.2,0.1$, and $0.05 \mu \mathrm{l}$ follicular fluid equivalent. Intra- and inter-assay coefficients of variation for $\mathrm{P}_{4}$ in follicular fluid were 6.3 and $6.8 \%$, respectively. Assay sensitivity was $23 \mathrm{pg} / \mathrm{ml}$.

Concentrations of $\mathrm{E}_{2}$ in plasma samples were determined by RIA (Kojima et al., 1992). Recovery of $\left[{ }^{3} \mathrm{H}\right] \mathrm{E}_{2}$ after extraction averaged $89.6 \pm 3.8 \%$ in six assays. Intra- and inter-assay coefficients of variation for $\mathrm{E}_{2}$ were 2.6 and $15.8 \%$, respectively. Assay sensitivity was $0.4 \mathrm{pg} / \mathrm{ml}$. Concentrations of $\mathrm{E}_{2}$ in non-extracted follicular fluid samples were determined by RIA (Kojima et al., 1992). Validation was performed as follows: serial dilutions of different pooled samples of bovine follicular fluid exhibited parallelism with the standard curve when follicular fluid pools and the standard curve were compared $(P=0.712)$ using the ALLFIT program (DeLean et al., 1978). Recovery of six different amounts of $E_{2}(0.4$, $0.8,1.6,3.2$, and $12.8 \mathrm{pg}$ ) added to $100 \mu \mathrm{l}$ of diluted follicular fluid pools $(0.1,0.05$, and $0.0125 \mu \mathrm{l}$ follicular fluid equivalent) averaged $102.6 \pm 6.5 \%$. Concentrations of $\mathrm{E}_{2}$ were 
determined in a single assay, and volumes of diluted follicular fluid samples used in this assay were 0.2 and $0.1 \mu \mathrm{l}$ follicular fluid equivalent. An intra-assay coefficient of variation was $2.8 \%$, and assay sensitivity was $0.4 \mathrm{pg} / \mathrm{ml}$. Amount of $\mathrm{P}_{4}$ and $\mathrm{E}_{2}$ in each sample was determined with a Four Parameter Curve Fitting Program (Grotjan and Steinberger, 1977).

Concentrations of $\mathrm{A}_{4}$ in follicular fluid were determined in one assay by RIA (Roberts and Skinner, 1990). The intra-assay coefficient of variation was $8.8 \%$. Assay sensitivity was $8 \mathrm{pg} / \mathrm{ml}$.

\subsection{Ligand-blot analysis of IGFBPs}

Follicular fluid samples were submitted to one-dimensional SDS-PAGE (Laemmli, 1970) to determine activity of IGFBPs by a ligand-blot procedure (Echternkamp et al., 1994; Hossenlopp et al., 1986). Follicular fluid samples were diluted 10-fold (1:10) with $0.01 \mathrm{M}$ phosphate buffer ( $\mathrm{pH} 7.4$ ), and $10 \mu \mathrm{l}$ of each dilution ( $1 \mu \mathrm{l}$ follicular fluid equivalent) was added to $20 \mu \mathrm{l}$ gel loading buffer $(62.5 \mathrm{mM}$ Tris base, $2 \%$ SDS, $0.02 \%$ bromophenol blue, and $10 \%$ glycerol, $\mathrm{pH}$ 6.8). Samples were boiled for $4 \mathrm{~min}$, placed on ice for 5-10 min, loaded into wells, and electrophoresed through a $4 \%$ stacking gel and a $12 \%$ polyacrylamide separating gel. Proteins were electrophoretically transferred to a nitrocellulose membrane, and IGFBP activity was detected by incubating membranes with $\left[{ }^{125} \mathrm{I}\right]$ IGF-I $(5,000,000 \mathrm{cpm} / 5 \mathrm{ml} 0.01 \mathrm{M}$ Tris buffered saline containing 3\% Triton X-100, $1 \%$ BSA (catalog no. A-7030, Sigma Chemical Co., St. Louis, MO), and 0.1\% Tween-20 per two nitrocellulose membranes). Membranes were placed with autoradiographic film (Kodak X-Omat, Eastman Kodak, Rochester, NY) for 7 days at $-80^{\circ} \mathrm{C}$. Banding intensity on exposed films was subsequently characterized by LKB Bromma UltraScan XL Laser Densitometer (Pharmacia LKB, Uppsala, Sweden). The gel and transfer apparatuses were of sufficient capacity (i.e. four 15-lane gels) to evaluate all samples at the same time using the same batch of reagents. Samples were stratified by treatment group across gels. A pool of bovine follicular fluid from small follicles was included on each gel as a positive control. Values for activity of IGFBPs obtained for the positive control sample on each gel were tested as a covariate to adjust for differences among gels. The covariate term, however, was not significant and was removed from the model.

\subsection{Statistical analyses}

Mean concentrations of $\mathrm{LH}$, frequency of pulses, and amplitude of pulses for $\mathrm{LH}$ in blood serum on Days 7, 12, and 16 were calculated by use of algorithms ((Merriam and Watcher, 1982); Pulsar, software modified for the IBM-PC by J.F. Gitzen and V.D. Ramirez, Urbana, IL). The $G$-values used for the Pulsar program were 5.5, 4.4, 1.6, 1.3, and 10.0 for G (1)-G (5), respectively.

Treatment effects on pattern of LH release on Days 7, 12, and 16 were analyzed independently for each day as a completely randomized design (Steele and Torrie, 1980) by least squares using the general linear model procedure of SAS (SAS, 1992). Treatment means were compared using Duncan's New Multiple Range test (Steele and Torrie, 1980). Concentrations of $\mathrm{P}_{4}, \mathrm{E}_{2}$, and $\mathrm{FSH}$ in blood during the treatment period were analyzed using a mixed model procedure of SAS (SAS, 1992). The fitted model included treatment, day and 
treatment by day as fixed effects and cow as a random effect. To account for the covariance among observations from the same animal at different days, different options of covariance structures for residuals available in the Repeated Statement of the mixed model procedure were considered; the model with the best fit was chosen for the final analyses. Treatment means were compared with the $t$-test of a mixed model procedure of SAS (SAS, 1992).

Concentrations of $\mathrm{A}_{4}, \mathrm{P}_{4}, \mathrm{E}_{2}$, and activity of IGFBPs in follicular fluid were log transformed $\left(\log _{10} X+1\right)$ before analyses due to heterogeneity of variances. Data were analyzed as a completely randomized design (Steele and Torrie, 1980) by least squares using the general linear model procedure of SAS (SAS, 1985). Treatment means were compared by Duncan's New Multiple Range test (Steele and Torrie, 1980). Growth characteristics of follicles were also analyzed as a completely randomized design (Steele and Torrie, 1980) by least squares procedure using the general linear models procedure of SAS (SAS, 1985). Treatment means were compared by Duncan's New Multiple Range test (Steele and Torrie, 1980). Residual correlations among follicular fluid concentrations of steroids and activity of IGFBPs within follicle classes were obtained using the MANOVA procedure of SAS (SAS, 1985).

\section{Results}

\subsection{Concentrations of $P_{4}$ and $E_{2}$ in plasma}

Targeted plasma concentrations of $\mathrm{P}_{4}$ for the 2PRID (5-9 ng/ml of plasma) and 0.5PRID $(1-3 \mathrm{ng} / \mathrm{ml}$ ) treatments were achieved in the present study (Fig. 1). On Days 0 and 1 of treatment, concentrations of $\mathrm{E}_{2}$ were not different $(P>0.10)$ in plasma among all groups (Fig. 2). From Day 2 to the end of treatment, plasma concentrations of $E_{2}$ increased and were subsequently greater $(P<0.05)$ in the plasma from the 0.5 PRID group compared with the 2PRID group. From Day 9 to the end of treatment, concentrations of $E_{2}$ in the plasma from the 0.5-2PRID group decreased $(P<0.05)$ after dose of $\mathrm{P}_{4}$ was increased and were similar to concentrations of $E_{2}$ observed in the 2PRID group. In contrast from Day 9 to the end of treatment, concentrations of $E_{2}$ in plasma from the 2-0.5PRID group increased $(P<0.05)$ after dose of $\mathrm{P}_{4}$ was decreased, and were similar to the 0.5PRID group (Fig. 2). From Day 2 (Day 7 of the estrous cycle) through Day 11 (Day 16 of the estrous cycle), concentrations of $E_{2}$ in plasma from control females were similar to those in females treated with two PRIDs. After Days 11-14 (Days 17-19 of the estrous cycle), concentrations of $\mathrm{E}_{2}$ increased $(P<0.05)$ in plasma from the control group and were similar to the 0.5PRID group. Subsequently, on Days 15 and 16 (Days 20 and 21 of the estrous cycle), concentrations of $\mathrm{E}_{2}$ in plasma from control females declined $(P<0.05)$ to those similar to females treated with two PRIDs (Fig. 2).

\subsection{Concentrations of LH and FSH in serum or plasma}

A greater $(P<0.05)$ frequency of LH pulses (Table 3) was observed during the $12 \mathrm{~h}$ serial blood collection periods on Days 7, 12, and 16 of the treatment period in females treated with a half PRID compared with females treated with two PRIDs. On Day 12, 


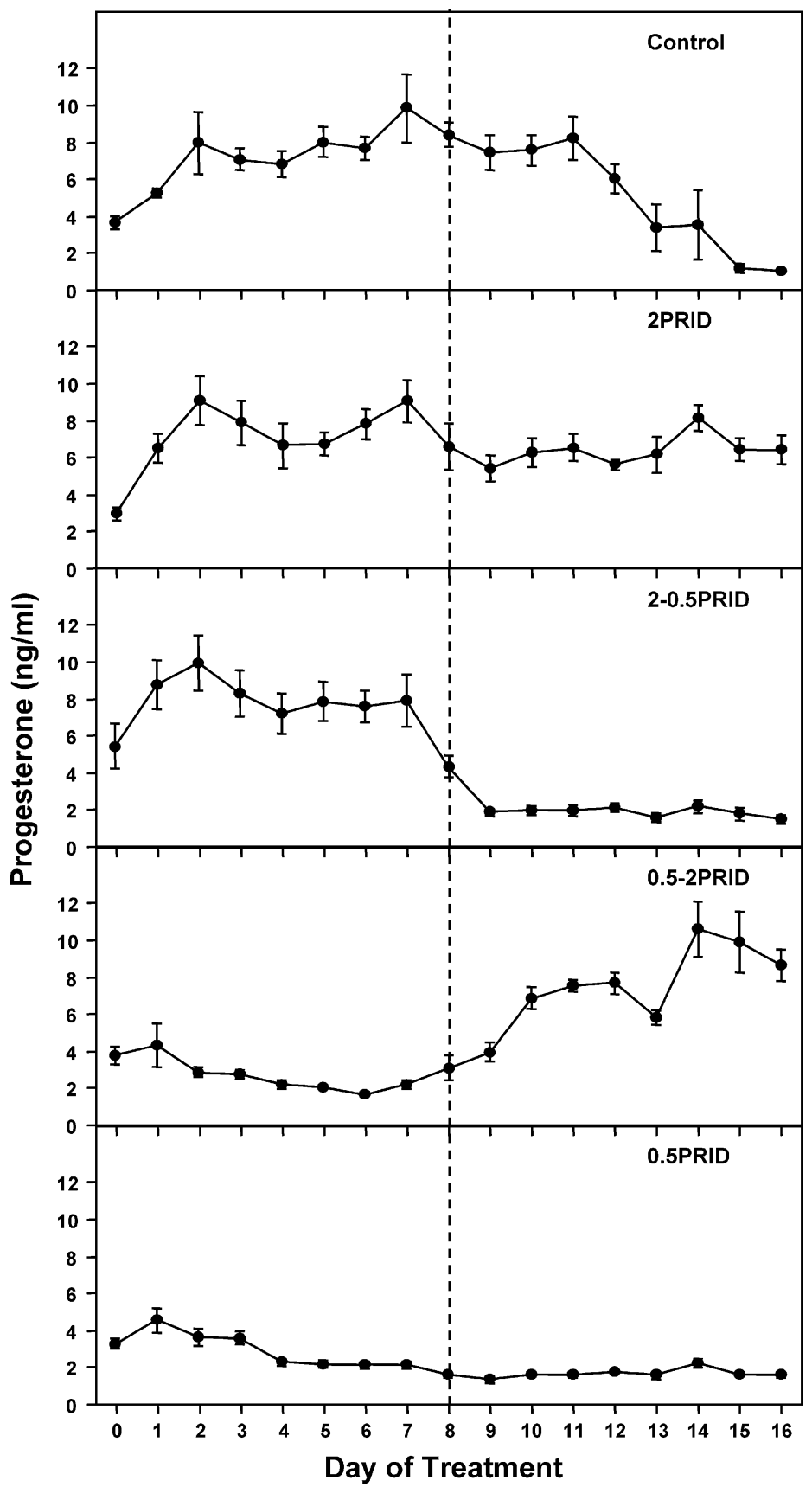

Fig. 1. Mean concentrations of progesterone in plasma samples during the treatment period (2PRID, $n=7$; 2-0.5PRID, $n=7$; 0.5-2PRID, $n=7$; 0.5PRID, $n=7$; control, $n=5$ ). 


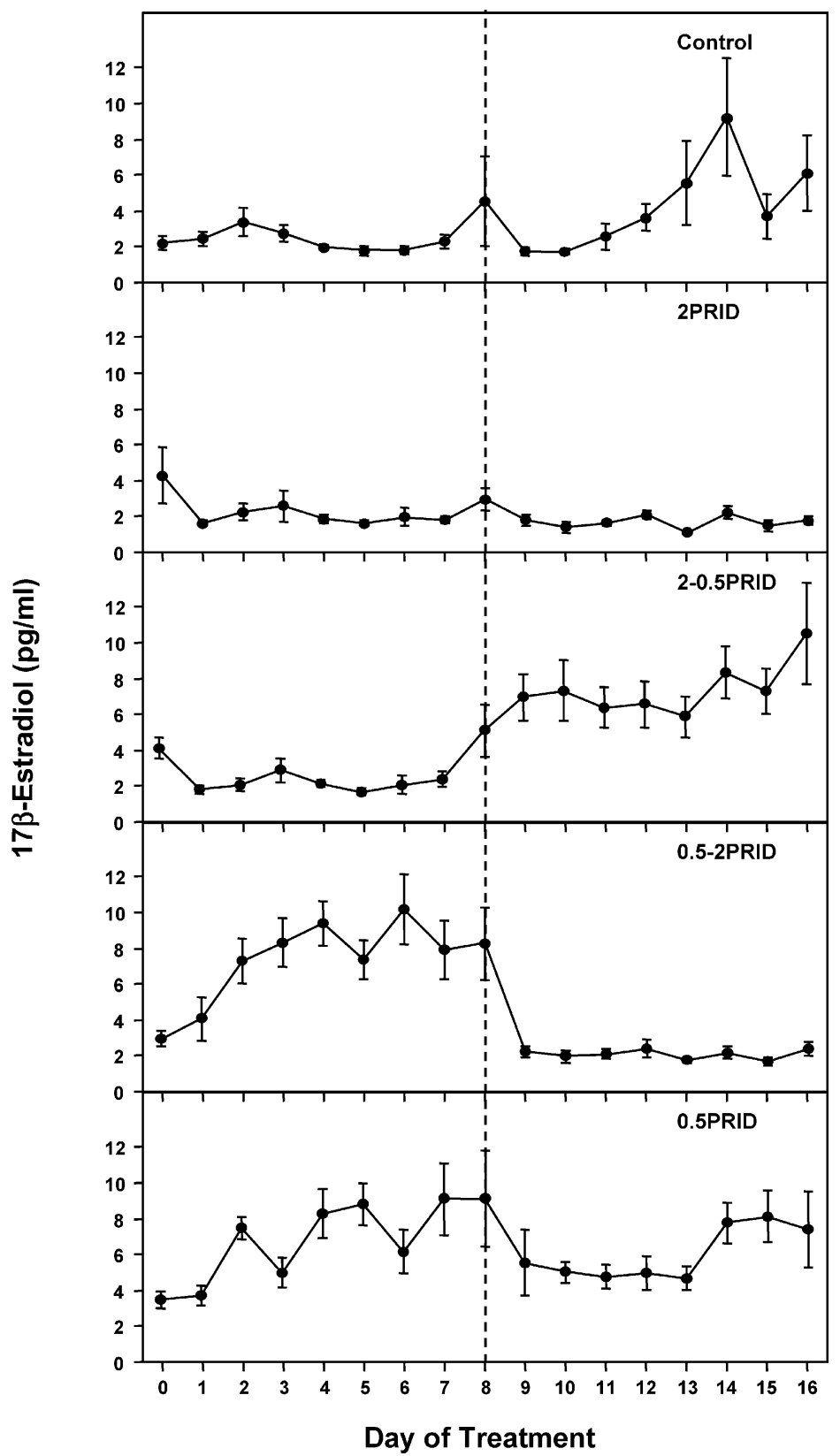

Fig. 2. Mean concentrations of $17 \beta$-estradiol in plasma samples during the treatment period (2PRID, $n=7$; 2-0.5PRID, $n=7$; 0.5-2PRID, $n=7$; 0.5PRID, $n=7$; control, $n=5$ ). 
Table 3

Frequency of LH pulses during serial blood collections on Days 7, 12, and 16 of the treatment period

\begin{tabular}{lllll}
\hline Treatment $^{\mathrm{b}}$ & \multicolumn{4}{l}{ Frequency of LH pulses $(\text { pulses/12 } \mathrm{h})^{\mathrm{a}}$} \\
\cline { 2 - 4 } & $n$ & Day 7 & Day 12 & Day 16 \\
\hline 2PRID & 7 & $3.14 \mathrm{e}$ & $2.43 \mathrm{~d}$ & $2.71 \mathrm{~d}$ \\
2-0.5PRID & 7 & $4.71 \mathrm{e}$ & $7.43 \mathrm{c}$ & $7.71 \mathrm{c}$ \\
$0.5-2$ PRID & 7 & $7.00 \mathrm{~d}$ & $3.00 \mathrm{~d}$ & $3.71 \mathrm{~d}$ \\
0.5PRID & 7 & $9.29 \mathrm{c}$ & $8.00 \mathrm{c}$ & $7.14 \mathrm{c}$ \\
Control & 5 & $0.80 \mathrm{f}$ & $2.80 \mathrm{~d}$ & 0.46 \\
Pooled S.E.M. & & 0.75 & 0.83 & \\
\hline
\end{tabular}

Numbers with differing letters $(\mathrm{c}, \mathrm{d}, \mathrm{e}, \mathrm{f})$ within a column differ $(P<0.05)$.

${ }^{a}$ Determined with Pulsar Software.

${ }^{\mathrm{b}}$ See Section 2 for definition of abbreviations and explanation of treatment regimens.

${ }^{\mathrm{c}}$ Pooled standard error of mean (S.E.M.).

mean concentrations of LH were greater $(P<0.05)$ in the 0.5PRID and control (Day 17 of the estrous cycle) groups compared with the 2PRID group. The 2-0.5PRID group had intermediate concentrations of LH on Day 12. Changes in concentrations of LH in plasma on Days 7, 12, and 16 for individual females from each group are depicted in Fig. 3. Characteristics of $\mathrm{LH}$ release around the time of change in doses of $\mathrm{P}_{4}$ were previously reported, and expected shifts in frequency of LH pulses occurred within $6 \mathrm{~h}$ of treatment shifts in dose of $\mathrm{P}_{4}$ (Bergfeld et al., 1996). Mean concentrations of FSH during the treatment period were less $(P<0.05)$ in the 2-0.5PRID group on Days 9-11 and the control group on Days 3, 7-9, and 15 compared with other groups. In contrast, mean concentrations of FSH were greater $(P<0.05)$ in the 2PRID group on Days $2,3,7-10$, and 14 compared to other groups (Fig. 4). Daily plasma samples analyzed for FSH, however, were not frequent enough to recognize a subtle increase in concentration of FSH preceding emergence of a new wave of follicular development in some cows.

\subsection{Pattern of ovarian follicular development observed by ultrasonography}

At initiation of treatment on Day 0 ( 5 days after behavioral estrus), diameter of the largest follicle detected in ovaries of all females was not different (data not shown; $P>0.10$ ). Length of growth phase of the largest follicle at the time of tissue collection was longer $(P<0.05)$ in the 2-0.5PRID group compared with the 2PRID, 0.5-2PRID, and control groups, while the 0.5PRID group was intermediate. The control group had a greater $(P<$ $0.05)$ growth rate of the ovulatory follicle than that of the largest follicle preceding the time of ovarian collection (control group, $1.8 \pm 0.1 \mathrm{~mm} /$ day; treatment groups, $1.2-1.4 \pm$ $0.1 \mathrm{~mm} /$ day; see Table 4). Growth rate of non-ovulatory follicles in the control group, however, was not different $(P>0.10)$ from $\mathrm{P}_{4}$-treated groups (first wave $(n=5) 1.2 \pm$ 0.1 , and second wave $(n=4) 1.1 \pm 0.1 \mathrm{~mm} /$ day $)$. Mean numbers of waves of follicular development were greater $(P<0.05)$ in the 2PRID and control groups compared with the 2-0.5PRID group. The control group $(n=5)$ had a typical pattern of follicular development with four females ovulating from the dominant follicle of the third wave and one cow from 

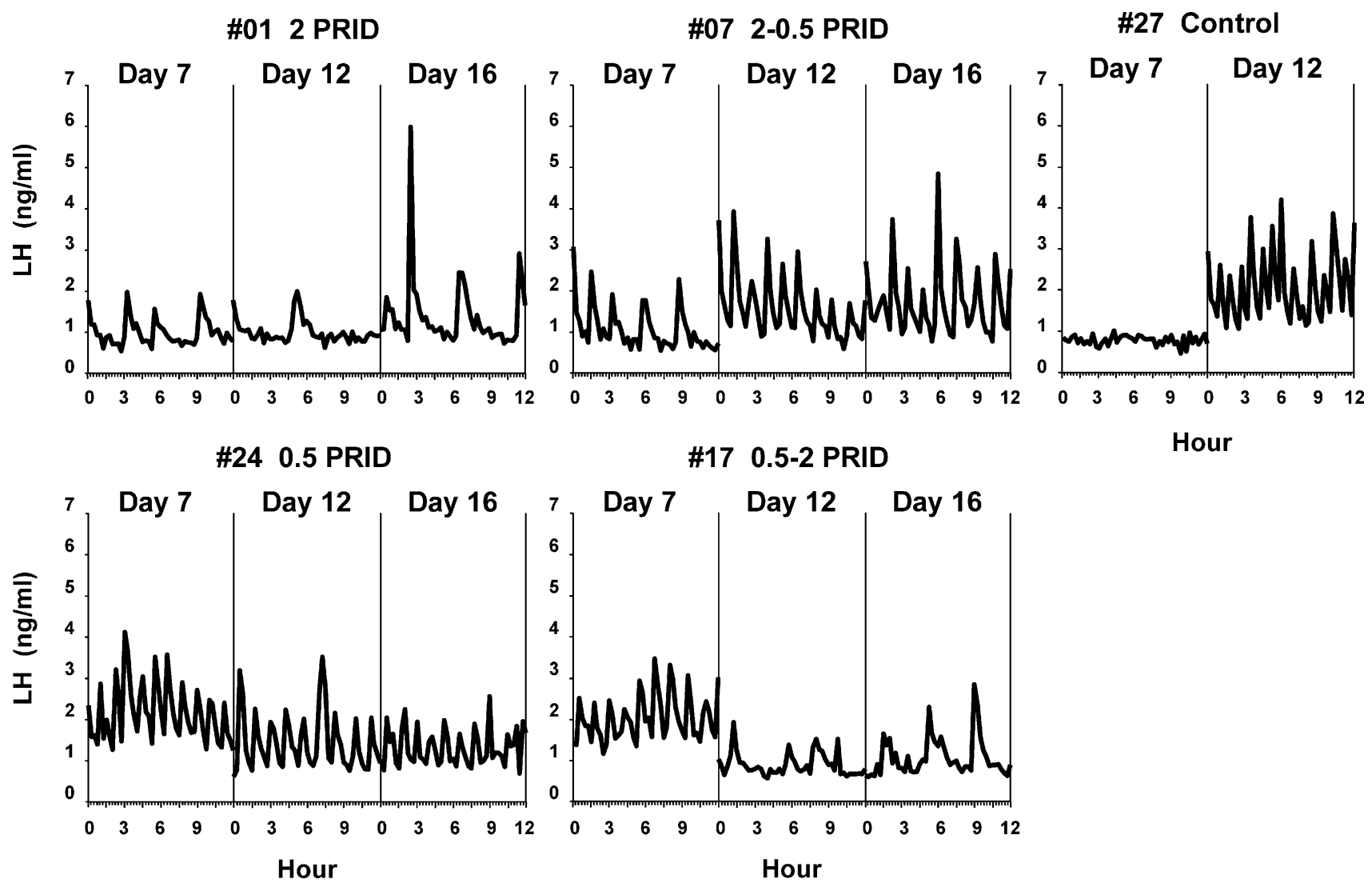

Fig. 3. Pattern of $\mathrm{LH}$ secretion ( $15 \mathrm{~min}$ intervals for $12 \mathrm{~h}$ ) of individual representative cows from each treatment group during serial blood collections on Days 7 , 12 , and 


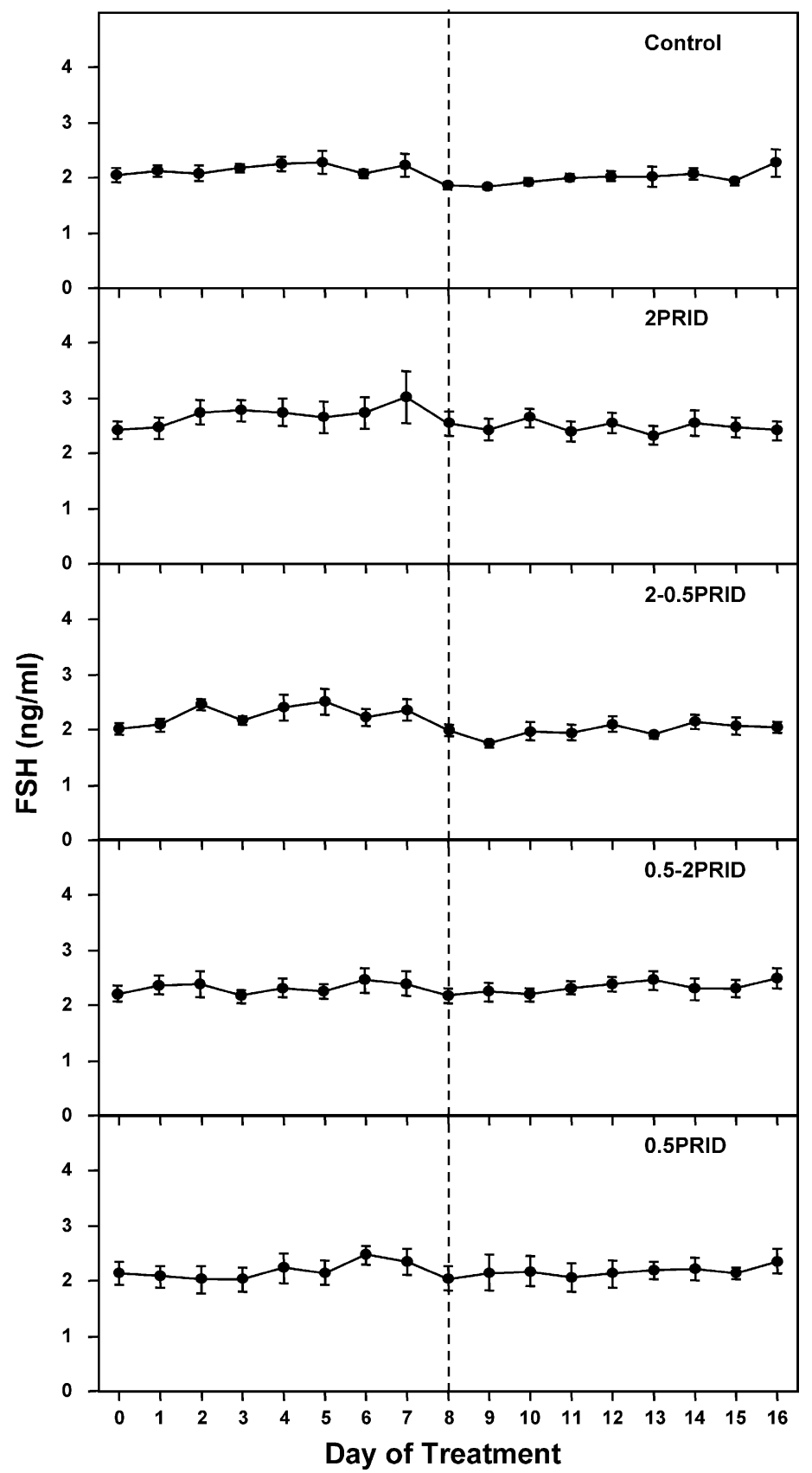

Fig. 4. Mean concentrations of FSH in plasma samples during the treatment period (2PRID, $n=7 ; 2-0.5$ PRID, $n=7$; 0.5-2PRID, $n=7$; 0.5PRID, $n=7$; control, $n=5$ ). 
Table 4

Growth characteristics of the largest follicle on Day 16 (mean \pm S.E.)

\begin{tabular}{|c|c|c|c|c|c|}
\hline Treatment $^{\mathrm{a}}$ & 2PRID & 2-0.5PRID & 0.5-2PRID & 0.5 PRID & Control \\
\hline Number in each group $(n)$ & 7 & 7 & 7 & 7 & 5 \\
\hline \multicolumn{6}{|l|}{ The largest follicle on Day $16^{\mathrm{b}}$} \\
\hline Diameter on Day 16 (mm) & $12.7 \pm 0.8 \mathrm{e}$ & $17.9 \pm 0.9 \mathrm{~d}$ & $12.3 \pm 0.9 \mathrm{e}$ & $15.4 \pm 0.9 \mathrm{~d}$ & $16.0 \pm 1.0 \mathrm{~d}$ \\
\hline Duration of detection (days) & $11.4 \pm 1.0$ ef & $13.4 \pm 0.9 \mathrm{de}$ & $16.0 \pm 1.2 \mathrm{~d}$ & $10.1 \pm 1.2 \mathrm{fg}$ & $7.4 \pm 1.2 \mathrm{~g}$ \\
\hline Growth phase (days) & $6.1 \pm 0.4 \mathrm{e}$ & $9.3 \pm 0.9 \mathrm{~d}$ & $6.9 \pm 1.2 \mathrm{e}$ & $7.4 \pm 0.8 \mathrm{de}$ & $6.6 \pm 0.4 \mathrm{e}$ \\
\hline Growth rate (mm/day) & $1.3 \pm 0.1 \mathrm{e}$ & $1.2 \pm 0.1 \mathrm{e}$ & $1.3 \pm 0.1 \mathrm{e}$ & $1.4 \pm 0.1 \mathrm{e}$ & $1.8 \pm 0.1 \mathrm{~d}$ \\
\hline Emergence of second wave (day) ${ }^{c}$ & $4.3 \pm 0.9 \mathrm{f}$ & $3.7 \pm 0.6 \mathrm{f}$ & $9.7 \pm 1.2 \mathrm{e}$ & $8.7 \pm 1.1 \mathrm{e}$ & $3.6 \pm 0.2 \mathrm{f}$ \\
\hline Emergence of third wave $(\text { day })^{\mathrm{c}}(n)$ & $12.2 \pm 0.7(n=6)$ & $14.0(n=1)$ & $12.5 \pm 0.5(n=3)$ & $12.7 \pm 0.7(n=3)$ & $12.3 \pm 1.0(n=4)$ \\
\hline Length of estrous cycle (days) & & & & & $21.4 \pm 0.7$ \\
\hline
\end{tabular}

Numbers with differing letters $(\mathrm{d}, \mathrm{e}, \mathrm{f}, \mathrm{g})$ within a row differ $(P<0.05)$.

${ }^{a}$ See Section 2 for definition of abbreviations and explanation of treatment regimens.

${ }^{b}$ Growth characteristics of largest follicles found on Day 16 from females of $\mathrm{P}_{4}$-treated groups, and the preovulatory follicle from females of control group; data based on ultrasonography beginning at the initiation of the treatment (Day $0=$ fifth day of the estrous cycle).

${ }^{c}$ Day of emergence of second and third wave of follicular development during the treatment period. 
the second wave of follicular development. Average length of the estrous cycle in control females was 21.4 days with a range from 19 to 23 days.

Classification of the largest follicle (F1) based solely on the ultrasonographic observation was influenced $(P<0.05)$ by treatment, with the 2PRID group having growing dominant and atretic follicles, the 2-0.5PRID group growing persistent follicles, the 0.5-2PRID group atretic persistent follicles, and the 0.5PRID group growing dominant and growing persistent follicles (Table 1). Classification of the F2 follicle based on the ultrasonography was also summarized in Table 1. When ultrasonography based classification of F1 follicles collected on Day 16 of treatment was re-classified based on follicular concentrations of $E_{2}$ and $\mathrm{P}_{4}$ (Table 2$)$, this classification was also influenced $(P<0.05)$ by treatment. The only difference $(P<0.05)$ observed was in the 2PRID group between two classifications, where all $\mathrm{F} 1$ follicles in this group were classified as atretic follicles. The largest follicle from each female in the 2PRID group resulted from the second (5/7) or third (2/7) wave of follicular development. Although some follicles appeared as a growing dominant follicle (either increasing in or maintaining size) by ultrasonographic observations and two follicles from the second wave of follicular development were lost during collection, all F1 follicles were classified as atretic by follicular concentration of steroids. In the 2-0.5PRID group, the largest growing follicles that were present at time of PRID treatment change developed to larger sizes typical of persistent follicles. At the end of treatment, the largest follicles from six of seven animals in this group were from the second wave of follicular development. All follicles from this group were characterized as growing persistent follicles. Follicular fluid from one follicle of this group was lost during collection. In contrast, the largest follicle in each female from the 0.5-2PRID group was from the first wave of follicular development and classified as atretic persistent follicles. Each of these follicles was the largest follicle during the first 8 days while females were treated with a half PRID, and each of these follicles remained as the largest follicle throughout the 16-day treatment period. The largest follicle in six of the seven females from the 0.5PRID group was from the second wave and the follicle in one cow was from the first wave of follicular development. The largest follicle from four females in this group was classified as a growing dominant follicle ( $<10$ days of detection by ultrasonography), whereas the largest follicle in the remaining three animals was classified as a growing persistent follicle ( $>10$ days of detection by ultrasonography) on Day 16. Follicles in growing dominant, growing persistent, and atretic persistent classes were larger $(P<0.05)$ than follicles in $\mathrm{G}$ and A classes. Diameter of the largest follicle on Day 16 was greater $(P<0.05)$ in the 2-0.5PRID, 0.5PRID, and control groups compared with the 2PRID and 0.5-2PRID groups (Table 4). Length of the growth phase of the largest follicle was longer $(P<0.05)$ in the 2-0.5PRID group compared with the 2PRID, 0.5-2PRID, and control groups, while the 0.5PRID group was intermediate for this variable (Table 4).

Classification of the F2 follicles collected on Day 16 of treatment based on the concentrations of $\mathrm{E}_{2}$ and $\mathrm{P}_{4}$ is summarized in Table 2. Fluid from the second largest follicle from two females of the 2PRID group was lost during processing. Each female in the 2-0.5PRID group had only one follicle greater than $7 \mathrm{~mm}$; therefore, the second largest follicle from each animal was not analyzed for this group. Of the second largest follicles analyzed in the other groups, none were classified as growing persistent follicles. The second largest follicle from each female in the 0.5PRID group was classified as an atretic persistent $(n=3)$, atretic 
$(n=3)$, or growing $(n=1)$ follicle. The second largest follicle from each animal in the 2PRID or 0.5-2PRID groups was classified as either a growing or atretic follicle (Table 2). Fig. 5 depicts representative patterns of follicular development during the treatment period for each group.

\subsection{Follicular fluid concentrations of steroid hormones and IGFBPS}

Classifying follicles into the five groups resulted in concentrations of hormones in follicular fluid and activity of the IGFBPs being consistent with these classifications. Because concentrations of $\mathrm{E}_{2}$ and $\mathrm{P}_{4}$ were a criteria for classification, growing dominant, growing persistent, and growing follicles contained greater $\mathrm{E}_{2}$ and $\mathrm{P}_{4}(P<0.05)$ than atretic or atretic persistent follicles (Table 5). Concentrations of $\mathrm{A}_{4}$ were greater $(P<0.05)$ in growing dominant follicles than growing, atretic, or atretic persistent follicles, while concentrations of $\mathrm{A}_{4}$ in growing persistent follicles were intermediate. Also as expected as a function of the follicle classification, concentrations of $\mathrm{P}_{4}$ were greater $(P<0.05)$ in atretic and atretic persistent follicles than growing, growing dominant, and growing persistent follicles (Table 5).

Six bands of IGFBPs were detected via ligand blot analysis. These bands have previously been identified as IGFBP-3 (a doublet at 44 and $40 \mathrm{kDa}$ ), IGFBP-2 (34 kDa), IGFBP-5 (a doublet at 31 and $29 \mathrm{kDa}$ ), and IGFBP-4 (a doublet at 28 and $24 \mathrm{kDa}$ ) (Echternkamp et al., 1994; Funston et al., 1996). Binding by $28-29 \mathrm{kDa}$ proteins (29 kDa form of IGFBP-5 and $28 \mathrm{kDa}$ form of IGFBP-4) could not always be distinctly separated in the ligand blots, therefore, binding in the $28-29 \mathrm{kDa}$ region was analyzed as one band. Bands representing IGFBP-3 were detected in all samples, but binding was less intense $(P<0.05)$ in growing dominant and growing persistent follicles as compared with other follicles (Table 5). Relative activity of IGFBP-2 was least $(P<0.05)$ in growing dominant follicles and less $(P<0.05)$ in growing and growing persistent follicles as compared with atretic and atretic persistent follicles. Relative activity of $31 \mathrm{kDa}$ IGFBP-5, 28-29kDa IGFBP and $24 \mathrm{kDa}$ IGFBP-4 was greater $(P<0.05)$ in atretic and atretic persistent follicles as compared with growing dominant, growing persistent, and growing follicles (Table 5). Concentrations of steroid hormones and activity of IGFBPs did not differ $(P>0.10)$ between atretic and atretic persistent follicles. However, growing dominant follicles had greater $(P<0.05)$ concentrations of $\mathrm{E}_{2}$ and $\mathrm{A}_{4}$, and less $(P<0.05)$ activity of IGFBP-3 and -2 than growing follicles, and less $(P<0.05)$ activity of IGFBP-2 as compared with growing persistent follicles (Table 5).

Evaluation of the residual correlations among steroid concentrations and IGFBP activities demonstrated that total integrated binding intensity for all the IGFBP bands was negatively correlated with concentrations of $\mathrm{E}_{2}(r=-0.51 ; P=0.001)$ and $\mathrm{A}_{4}(r=-0.24$; $P=0.0004)$, and positively correlated with $\mathrm{P}_{4}(r=0.42 ; P=0.0001)$ in all follicle classifications. In growing follicles (G, GD, and GP), concentration of $\mathrm{E}_{2}$ was negatively correlated with activity of IGFBP-2 $(r=-0.54 ; P=0.01),-5(r=-0.43 ; P=0.05)$, $28-29 \mathrm{kDa}(r=-0.77 ; P=0.0001)$, and $-4(r=-0.78 ; P=0.0001)$. In growing, growing dominant, and growing persistent follicles, concentration of $\mathrm{P}_{4}$ was negatively correlated with activity of IGFBP-5 $(r=-0.43 ; P=0.05)$ and the $28-29 \mathrm{kDa}$ form of IGFBP $(r=-0.46 ; P=0.04)$. Concentration of $\mathrm{E}_{2}$ tended to be negatively correlated 
\#08 2-0.5 PRID

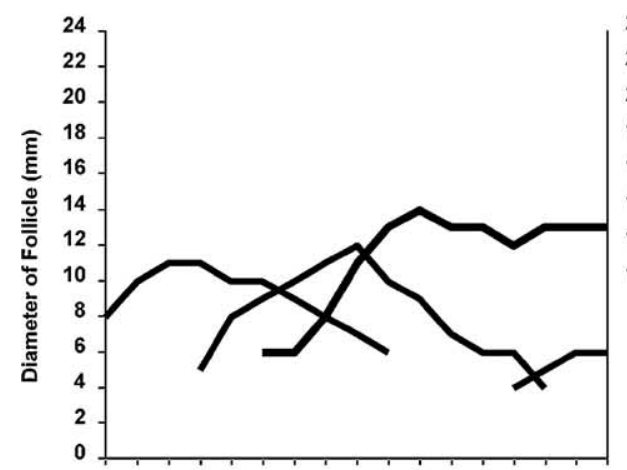

\#24 0.5 PRID

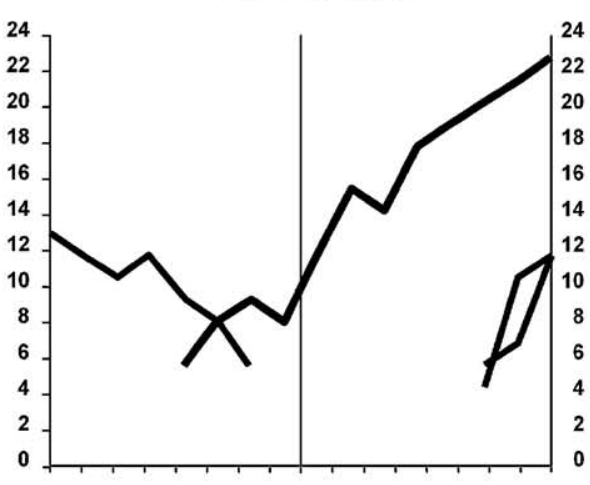

\#16 0.5-2 PRID
\#25 Control

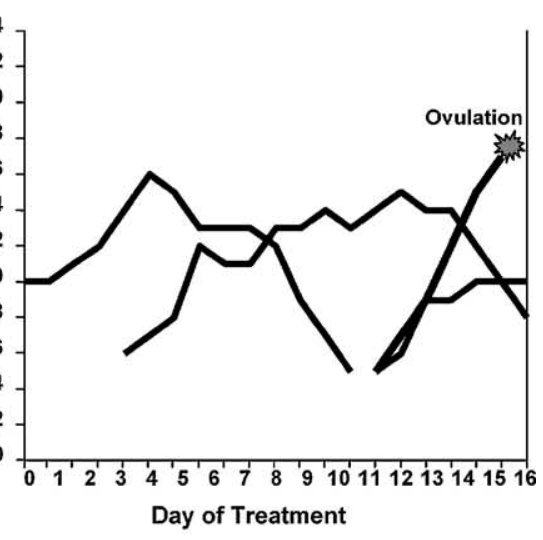

Day of Treatment
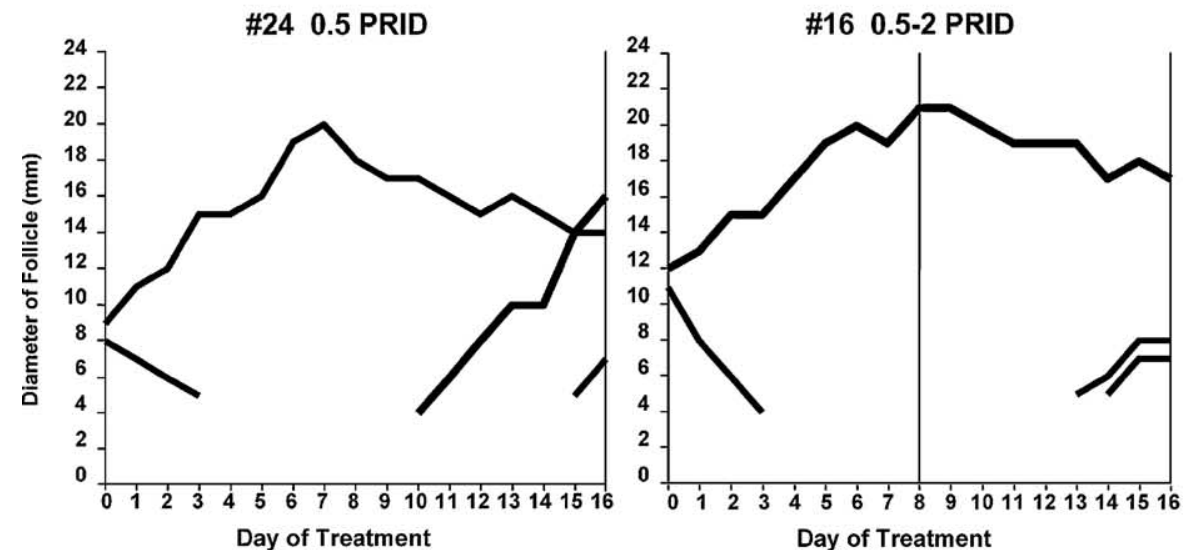

Day of Treatment

Day of Treatment

Fig. 5. Pattern of ovarian follicular development from individual representative cows from each treatment group with bold lines indicating the largest follicle collected on Day 16 in cows treated with progesterone or the preovulatory follicle in a control cow. 
Table 5

Mean diameter and concentrations of $17 \beta$-estradiol $\left(\mathrm{E}_{2}\right)$, androstenedione $\left(\mathrm{A}_{4}\right)$, progesterone $\left(\mathrm{P}_{4}\right)$ and IGFBP activity in follicular fluid of different types of follicles

\begin{tabular}{|c|c|c|c|c|c|c|c|c|c|c|}
\hline \multirow{2}{*}{$\begin{array}{l}\text { Follicle } \\
\text { classification }^{\mathrm{b}}\end{array}$} & \multirow[t]{2}{*}{$n$} & \multirow{2}{*}{$\begin{array}{l}\text { Follicle } \\
\text { diameter } \\
(\mathrm{mm})\end{array}$} & \multirow{2}{*}{$\begin{array}{l}\mathrm{E}_{2} \\
(\mathrm{ng} / \mathrm{ml})\end{array}$} & \multirow{2}{*}{$\begin{array}{l}\mathrm{A}_{4} \\
(\mathrm{ng} / \mathrm{ml})\end{array}$} & \multirow{2}{*}{$\begin{array}{l}\mathrm{P}_{4} \\
(\mathrm{ng} / \mathrm{ml})\end{array}$} & \multicolumn{5}{|c|}{ Densitometer units ${ }^{\mathrm{a}}$} \\
\hline & & & & & & IGFBP-3 & IGFBP-2 & 31 kDa IGFBP-5 & $28-29 \mathrm{kDa}$ IGFBP & $24 \mathrm{kDa}$ IGFBP-4 \\
\hline GP & 9 & $17.0 \mathrm{c}$ & $122.0 \mathrm{c}$ & $39.2 \mathrm{~cd}$ & $37.4 \mathrm{~d}$ & $11.5 \mathrm{e}$ & $4.1 \mathrm{~d}$ & $0.3 \mathrm{~d}$ & $0.7 \mathrm{~d}$ & $0.3 \mathrm{~d}$ \\
\hline G & 8 & $9.2 \mathrm{e}$ & $12.7 \mathrm{~d}$ & $37.8 \mathrm{de}$ & $28.2 \mathrm{~d}$ & $13.2 \mathrm{~d}$ & $5.0 \mathrm{~d}$ & $0.3 \mathrm{~d}$ & $1.3 \mathrm{~d}$ & $1.1 \mathrm{~d}$ \\
\hline $\mathrm{AP}$ & 10 & $12.3 \mathrm{~d}$ & $2.4 \mathrm{e}$ & $11.0 \mathrm{e}$ & $366.8 \mathrm{c}$ & $14.1 \mathrm{c}$ & $7.4 \mathrm{c}$ & $3.0 \mathrm{c}$ & $3.3 \mathrm{c}$ & $2.3 \mathrm{c}$ \\
\hline A & 12 & $9.6 \mathrm{e}$ & $1.5 \mathrm{e}$ & $22.6 \mathrm{de}$ & $378.3 \mathrm{c}$ & $13.7 \mathrm{c}$ & $7.1 \mathrm{c}$ & $4.0 \mathrm{c}$ & $4.2 \mathrm{c}$ & $3.7 \mathrm{c}$ \\
\hline Pooled S.E.M. ${ }^{\mathrm{c}}$ & & 0.8 & 11.6 & 6.8 & 35.4 & 0.3 & 0.4 & 0.4 & 0.3 & 0.3 \\
\hline
\end{tabular}

Numbers with differing letters (c, d, e) within a column differ $(P<0.05)$.

a Values are the least square mean expressed in densitometer units.

${ }^{\mathrm{b}}$ Classification of largest follicles by ultrasonographic observations were: growing (G), growing dominant (GD), growing persistent (GP), atretic (A), and atretic persistent (AP). See Section 2 for definition of other abbreviations.

${ }^{\mathrm{c}}$ Pooled standard error of mean (S.E.M.). 
with activity of IGFBP-3 $(r=-0.62 ; P=0.07)$ in growing persistent follicles and was positively correlated with activity of IGFBP-3 $(r=0.87 ; P=0.006)$ in growing follicles. In atretic follicles (A and AP), concentration of $\mathrm{E}_{2}$ was negatively correlated with activity of IGFBP-3 $(r=-0.53 ; P=0.01),-5(r=-0.80 ; P=0.0001), 28-29 \mathrm{kDa}(r=-0.80$; $P=0.0001)$, and $-4(r=-0.71 ; P=0.0003)$. In atretic follicles, concentration of $\mathrm{P}_{4}$ was positively correlated with activity of IGFBP-3 $(r=0.45 ; P<0.03),-5(r=0.87$; $P=0.0001), 28-29 \mathrm{kDa}(r=0.62 ; P=0.002)$, and $-4(r=0.44 ; P=0.005)$.

\section{Discussion}

The present study yielded results indicating concentrations of steroid hormones in follicular fluid and blood plasma could be predictably controlled by regulating the frequency of LH pulses with varying doses of $\mathrm{P}_{4}$. Follicular atresia in the present study was associated with increased follicular fluid activity of IGFBP-2, $-4,-5$, and $\mathrm{P}_{4}$, whereas growing dominant and persistent follicles contained greater concentrations of $\mathrm{E}_{2}, \mathrm{~A}_{4}$, and less IGFBP-2 activity as compared with follicles of other classes.

A significant finding in the present study was that continued frequent release of LH pulses throughout the 16-day period in the 0.5PRID group (Fig. 3) failed to support the continuous growth of the largest follicles for 16 days (Fig. 5). Regardless of the sustained increase in frequency of LH pulses achieved by the half PRID treatment, the largest follicle from the first wave of follicular development in this group had a finite life span. The decline in plasma $\mathrm{E}_{2}$ between Days 9 and 12 in the 0.5PRID group indicates the period over which individual dominant follicles from the first wave of follicular development lost functional dominance. These persistent follicles were then replaced by follicles from the second wave of follicular development, which grew continuously to become the largest follicles in six of seven females of this group (Fig. 5). Growth characteristics of the largest follicle of the second wave of follicular development indicated that a greater frequency of LH pulses was able to stimulate these follicles to develop as second persistent follicles during the treatment period. A possible interpretation of these results is that persistent follicles have a specific life span or limitation in duration of dominance as indicated by the loss of dominance of the largest follicle that developed during the first wave of follicular development and decline in concentrations of $E_{2}$ in blood. Duration of dominance of a persistent follicle, therefore, seems to be finite, even when frequent LH pulses, which are known to stimulate continuous growth of follicles, are present (Cupp et al., 1992; Stock and Fortune, 1993; Taylor et al., 1993; Savio et al., 1993).

The developmental pattern of the first wave dominant follicle was similar between the 0.5PRID and 0.5-2PRID groups. When development of the largest follicle during a second wave of follicular development was compared between the 0.5PRID and 0.5-2PRID groups, development of this follicle was suppressed in the 0.5-2PRID compared with the 0.5PRID group. A reduction in frequency of LH pulses has been reported to occur within $6 \mathrm{~h}$ after changing from the small to large dose of $\mathrm{P}_{4}$ similar as in the 0.5-2PRID group (Bergfeld et al., 1996). The change from a relatively small to relatively large dose of progestin has been shown in previous research to induce loss of functional dominance and often atresia of persistent follicles, which is caused by the sudden decrease in frequency of LH pulses 
(McDowell et al., 1998). Despite a change in dose of $\mathrm{P}_{4}$ in the 0.5-2PRID group, the largest follicles persisted until the end of the 16-day treatment period, but lost dominance before the end of treatment period. In the 0.5-2PRID group, maintenance of these large follicles in the ovary after loss of functional dominance was similar to findings in a previous study (Anderson and Day, 1994).

The only difference in rate of growth among dominant follicles was the greater growth rate of the preovulatory follicles of the control group. The preovulatory follicles of the control group grew at a faster rate as compared with persistent or typically growing dominant follicles. Decreasing concentrations of $\mathrm{P}_{4}$ during luteolysis induced an increased frequency of LH pulses and consequently mean concentrations of LH (Imakawa et al., 1986; Cupp et al., 1995a; Cupp et al., 1995b). The rapid increase in frequency of LH pulses with luteolysis may have a role in the greater growth rates of preovulatory follicles in control females of the present study during the follicular phase of the estrous cycle compared with the growth rates of other dominant follicles that were evaluated.

All follicles were classified into five classes based on ultrasonographic observations (Table 1), then those follicles collected on Day 16 were re-classified based on follicular concentrations of $\mathrm{E}_{2}$ and $\mathrm{P}_{4}$ (Table 2). The only difference was found in $\mathrm{F} 1$ follicles from the 2PRID group between these two classifications: ultrasonographic observation determined three growing dominant and four atretic follicles, with one follicle each lost during collection for both classes, while the remaining five follicles (two GD and three A follicles by ultrasonography) were determined as atretic based on the follicular concentration of steroids. Although two follicles appeared as growing dominant follicles (either increasing in or maintaining size with inhibiting emergence of a new wave of follicle development) by ultrasonography, those follicles were atretic based on follicular steroid contents. These results indicated that ultrasonographic examination of dominant follicles did not correctly estimate functionality of follicles (dominant versus atretic). Conversely, biochemical characteristics of follicular atresia might have already been initiated before the emergence of the next wave of follicle development.

Classification (G, GD, GP, A, and AP) of the largest follicle present on Day 16 based on follicular concentration of steroids was influenced by treatment. The 2PRID group had atretic follicles, the 2-0.5PRID group had growing persistent follicles, the 0.5-2PRID group had atretic persistent follicles, and the 0.5PRID group had growing dominant and growing persistent follicles. Classification of the follicles into five groups is a function of concentrations of steroids in follicular fluid (Table 2). Concentrations of $E_{2}$ in follicular fluid, therefore, were greatest in growing dominant and growing persistent follicles compared with other types of follicles, and greater in growing follicles compared with atretic and atretic persistent follicles. The greater concentrations of $E_{2}$ observed in growing dominant and growing persistent follicles in the present study are in agreement with results from a previous study (Cupp et al., 1993). However, follicular fluid concentrations of $\mathrm{A}_{4}$ were greatest in growing dominant follicles compared with all other follicles. These results suggested that persistent follicles were able to maintain a capacity for estrogen synthesis for an extended period compared with other follicles, however, growing persistent follicles might have started to decrease their capacity for estrogen synthesis after 10 days of persistence. Conversely, as a function of follicle classification, concentrations of $\mathrm{P}_{4}$ in follicular fluid were greater in atretic and atretic persistent follicles compared with growing (G, GD, and 
GP) follicles. Although growing follicles were increasing in size, follicular fluid concentrations of $\mathrm{E}_{2}$ in these follicles were relatively less as compared with those of growing dominant and growing persistent follicles, but this may only be indicative of differences in developmental stages. An appropriate model to compare with growing and growing persistent follicles may have been previously described (Funston et al., 1996), in which preovulatory follicles contain greater concentrations of $\mathrm{E}_{2}$ and less activity of IGFBPs in follicular fluid, similar to persistent follicles.

Relative abundance of all IGFBPs was greater in atretic follicles (A and AP) than growing follicles (G, GD, and GP), and activity of the individual IGFBP was negatively associated with $\mathrm{E}_{2}$ concentration and positively correlated with $\mathrm{P}_{4}$ concentration. Activity of IGFBP-2 was less in GD follicles compared with all other follicles and less in G and GP follicles when compared with A and AP follicles. These results are in agreement with previous studies in follicles from cattle (Echternkamp et al., 1994), sheep (Monget et al., 1993), and humans (Cataldo and Guidice, 1992) where IGFBP-2 and other lesser molecular weight proteins were much more abundant in atretic follicles. Similar results have been reported for changes in concentrations of IGFBPs in follicular fluid samples collected during the first wave of follicular development in cattle (de la Sota et al., 1996). Activity of IGFBP-2, -4, and -5 was increased with atresia of dominant follicles and subordinate follicles compared with estrogen active dominant follicles, while follicular fluid concentrations of IGF-I and -II were relatively consistent in all types of follicles (de la Sota et al., 1996). There was also little variation in content of IGF-I in follicular fluid during different stages of the first wave of dominant follicle development during the estrous cycle (Badinga et al., 1992), and in preovulatory follicles around the time of behavioral estrus (Funston et al., 1996). Collectively, results from previous studies and the present study indicate that bioavailability of IGF-I in individual follicles may be regulated by IGFBPs and is associated with atresia of follicles.

Activity of IGFBP-3 was detected in all follicles but was less abundant in GD and GP follicles. Relative activity of IGFBP-3 was negatively correlated with $\mathrm{E}_{2}$ in GP follicles, whereas IGFBP-3 was positively correlated with $\mathrm{E}_{2}$ in $\mathrm{G}$ follicles. In pigs, follicular fluid concentrations of IGFBP-3 were relatively constant at different stages of follicular development, but decreased in preovulatory follicles (Mondschein et al., 1991; Howard and Ford, 1992). In sheep, slight, yet significant increases in IGFBP-3 activity occurred with increased follicular development (Monget et al., 1993). However, follicular fluid from preovulatory and non-ovulatory follicles of cattle had similar amounts of IGFBP-3 (Funston et al., 1996). It has been proposed (Grimes and Hammond, 1994) that follicular fluid IGFBP-3 may be derived from the vascularization, and that this protein may function as a transporter for IGF-I from blood into follicles. Therefore, decreased abundance of IGFBP-3 in GD and GP follicles in the present study may result from diminished vascularization in these follicles.

In conclusion, in the present study there were predictable effects on the concentration of steroid hormones when the frequency of LH pulses was considered. Maintenance of a frequent release of LH pulses over a 16-day period did not result in maintenance of persistent follicles throughout this period, indicating that duration of dominance of these follicles is finite even when there is frequent release of LH pulses. Follicular atresia in the present study was associated with increased follicular fluid activity of IGFBP-2, -4, -5, and concentrations 
of $\mathrm{P}_{4}$, whereas growing dominant and persistent follicles contained greater concentrations of $\mathrm{E}_{2}, \mathrm{~A}_{4}$, and less IGFBP-2 activity as compared with follicles of other classes.

\section{Acknowledgements}

We thank Karl Moline, Bob Browleit, and Jeff Bergman for managing the experimental animals; Shelia Schemm, Ken Pearson, and Bruce Melson for technical assistance; and Penny Bures for photographic services. We also thank Dr. Jerry Reeves for LH antisera; Dr. Leo Reichert Jr. for the purified LH and FSH; Dr. Jim Dias for FSH antisera; Dr. Norman Mason for $\mathrm{E}_{2}$ antisera; Dr. Ed Grotjan Jr. for the Four Fit Program used in the $\mathrm{E}_{2}$ and $\mathrm{P}_{4}$ assay analysis; and Pharmacia and Upjohn Co. for providing the Lutalyse ${ }^{\circledR}$ Sterile Solution. A very special thanks goes to all undergraduate students for countless hours of help during this experiment.

\section{References}

Acosta, B., Tarnavsky, G.K., Platt, T.E., Hamernik, D.L., Brown, J.L., Schoenemann, H.M., Reeves, J.J., 1983. Nursing enhances the negative effect of estrogen on LH release in the cow. J. Anim. Sci. 57, 1530-1536.

Adams, T.E., Kinder, J.E., Chakraborty, P.K., Estergreen, V.L., Reeves, J.J., 1975. Ewe luteal function influenced by pulsatile administration of synthetic LHRH/FSHRH. Endocrinology 97, 1460-1467.

Adashi, E.Y., Resnick, C.E., Hurwitz, A., Ricciarelli, E., Hernandez, E.R., Rosenfeld, R.G., 1991. Ovarian granulose cell-derived insulin-like growth factor binding proteins: modulatory role of follicle-stimulating hormone. Endocrinology 128, 754-760.

Anderson, L.H., Day, M.L., 1994. Acute progesterone administration regresses persistent dominant follicles and improves fertility of cattle in which estrus was synchronized with melengestrol acetate. J. Anim. Sci. 72, 2955-2961.

Badinga, L., Draincourt, M.A., Savio, J.D., Wolfenson, D., Drost, M., de la Sota, R.L., Thatcher, W.W., 1992. Endocrine and ovarian responses associated with the first-wave dominant follicle in cattle. Biol. Reprod. 47, 871-883.

Bergfeld, E.G.M., Kojima, F.N., Cupp, A.S., Wehrman, M.E., Peters, K.E., Mariscal, V., Sanchez, T., Kinder, J.E., 1996. Changing dose of progesterone results in sudden changes in frequency of luteinizing hormone pulses and secretion of $17 \beta$-estradiol in bovine females. Biol. Reprod. 54, 546-553.

Bigelow, K.L., Fortune, J.E., 1998. Characteristics of prolonged dominant versus control follicles: follicle cell numbers, steroidogenic capabilities and messenger ribonucleic acid for steroidogenic enzymes. Biol. Reprod. 58, 1241-1249.

Cataldo, N.A., Guidice, L.C., 1992. Insulin-like growth factor binding protein profiles in human ovarian follicular fluid correlate with follicular functional status. J. Clin. Endocrinol. Metab. 74 (4), 821-829.

Cupp, A.S., Garcia-Winder, M., Zamudio, A., Mariscal, V., Wehrman, M., Kojima, N., Peters, K., Bergfeld, E., Hernandez, P., Sanchez, T., Kittok, R., Kinder, J., 1992. Two concentrations of progesterone $\left(\mathrm{P}_{4}\right)$ in circulation have a differential effect on pattern of ovarian follicular development in the cow. Biol. Reprod. 44 (Suppl. 1), 64.

Cupp, A.S., Garcia-Winder, M., Zamudio, A., Mariscal, V., Wehrman, M., Kojima, N., Peters, K., Bergfeld, E., Hernandez, P., Sanchez, T., Kittok, R., Kinder, J., 1993. Concentration of progesterone $\left(\mathrm{P}_{4}\right)$ in circulation has a differential effect on biochemical characteristics of dominant follicles in cows. J. Anim. Sci. 71 (Suppl. 1), 211.

Cupp, A.S., Kojima, F.N., Roberson, M.S., Stumpf, T.T., Wolfe, M.W., Werth, L.A., Kittok, R.J., Grotjan, H.E., Kinder, J.E., 1995a. Increasing concentrations of $17 \beta$-estradiol has differential effects on secretion of luteinizing hormone and follicle-stimulating hormone and amounts of mRNA for gonadotropin subunits during the follicular phase of the bovine estrous cycle. Biol. Reprod. 52, 288-296. 
Cupp, A.S., Stumpf, T.T., Kojima, N., Werth, L.A., Wolfe, M.W., Roberson, M.S., Kittok, R.J., Kinder, J.E., 1995b. Secretion of gonadotrophins change during the luteal phase of the bovine oestrous cycle in the absence of corresponding changes in progesterone or 17 $\beta$-estradiol. Anim. Reprod. Sci. 37, 109-119.

de la Sota, R.L., Simmen, F.A., Diaz, T., Thatcher, W.W., 1996. Insulin-like growth factor system in bovine first-wave dominant and subordinate follicles. Biol. Reprod. 55, 803-812.

DeLean, A., Munson, P.J., Rodbard, D., 1978. Simultaneous analysis of families of sigmoidal curves: application to bioassay, radioligand assay, and physiological dose-response curves. Am. J. Physiol. 235, E97-E102.

Echternkamp, S.E., Howard, H.J., Roberts, A.J., Grizzle, J., Wise, T., 1994. Relationships among concentrations of steroids, insulin-like growth factor-1, and insulin-like growth factor binding proteins in ovarian follicular fluid in beef cattle. Biol. Reprod. 51, 971-981.

Erickson, G.F., Danforth, D.R., 1995. Ovarian control of follicle development. Am. J. Obstet. Gynecol. 172, 736-747.

Funston, R.N., Seidel Jr., G.E., Klindt, J., Roberts, A.J., 1996. Insulin-like growth factor I and insulin-like growth factor-binding proteins in bovine serum and follicular fluid before and after the preovulatory surge of luteinizing hormone. Biol. Reprod. 55, 1390-1396.

Giudice, L.C., 1992. Insulin-like growth factors and ovarian follicular development. Endocr. Rev. 13, 641-669.

Grimes, R.W., Hammond, J.M., 1994. Proteolytic degradation of insulin-like growth factor (IGF)-binding protein-3 by porcine ovarian granulosa cells in culture: regulation by IGF-I. Endocrinology 134, 337-343.

Grotjan Jr., H.E., Steinberger, E., 1977. Radioimmunoassay and bioassay data processing using a logistic curve fitting routine adapted to a desk top computer. Comput. Biol. Med. 7, 159-163.

Hammond, J.M., Mondschein, J.S., Samaras, S.E., Smith, S.A., Hagen, D.R., 1991. The ovarian insulin-like growth factor system. J. Reprod. Fert. 43 (Suppl.), 199-208.

Hillier, S.G., 1994. Hormonal regulation of folliculogenesis and luteinization. In: Findlay, J.K. (Ed.), Molecular Biology of the Female Reproductive System. Academic Press, San Diego, pp. 2-37.

Hossenlopp, P., Seurin, D., Segovia-Quinson, B., Hardouin, S., Binoux, M., 1986. Analysis of serum insulin-like growth factor binding proteins using western blotting: use of the method for titration of the binding proteins and competitive binding studies. Anal. Biochem. 154, 138-143.

Howard, H.J., Ford, J.J., 1992. Relationships among concentrations of steroids, inhibin, insulin-like growth factor-I (IGF-I), and IGF-binding proteins during follicular development in weaned sows. Biol. Reprod. 47, $193-201$.

Imakawa, K., Day, A.M., Zalesky, D.D., Garcia-Winder, M., Kittok, R.J., Kinder, J.E., 1986. Regulation of pulsatile LH secretion by ovarian steroids in the heifer. J. Anim. Sci. 63, 162-168.

Kojima, F.N., Stumpf, T.T., Cupp, A.S., Werth, L.A., Roberson, M.S., Wolfe, M.W., Kittok, R.J., Kinder, J.E., 1992. Exogenous progesterone and progestins as used in estrous synchrony regimens do not mimic the corpus luteum in regulation of luteinizing hormone and 17 $\beta$-estradiol in circulation of cows. Biol. Reprod. 47, 1009-1017.

Laemmli, U.K., 1970. Cleavage of structural proteins during the assembly of the head of bacteriophage T4. Nature $227,680-685$.

Manikkam, M., Rajamahendran, R., 1997. Progesterone-induced atresia of the proestrous dominant follicle in the bovine ovary: changes in diameter, insulin-like growth factor system, aromatase activity, steroid hormones, and apoptotic index. Biol. Reprod. 57, 580-587.

McDowell, C.M., Anderson, L.H., Kinder, J.E., Day, M.L., 1998. Duration of treatment with progesterone and regression of persistent ovarian follicles in cattle. J. Anim. Sci. 76, 850-855.

Merriam, G.K., Watcher, K.W., 1982. Algorithms for the study of episodic hormone secretion. Am. J. Physiol. 243, 310 .

Mondschein, J.S., Etherton, T.D., Hammond, J.M., 1991. Characterization of insulin-like growth factor-binding proteins of porcine ovarian follicular fluid. Biol. Reprod. 44, 315-320.

Monget, P., Monniauz, D., Pisselet, C., Durand, P., 1993. Changes insulin-like growth factor-I (IGF-I), IGF-II, and their binding proteins during the growth and atresia of ovine ovarian follicles. Endocrinology 132, 1438-1446.

Roberson, M.S., Wolfe, M.W., Stumpf, T.T., Kittok, R.J., Kinder, J.E., 1989. Luteinizing hormone secretion and corpus luteum function in cows receiving two levels of progesterone. Biol. Reprod. 41, 997-1003.

Roberts, A.J., Skinner, M.K., 1990. Hormonal regulation of thecal cell function during antral follicle development in bovine ovaries. Endocrinology 127, 2907-2917.

Sanchez, T., Wehrman, M.E., Bergfeld, E.G., Peters, K.E., Kojima, F.N., Cupp, A.S., Mariscal, V., Kittok, R.J., Rasby, R.J., Kinder, J.E., 1993. Pregnancy rate is greater when the corpus luteum is present during the period of progestin treatment to synchronize time of estrus in cows and heifers. Biol. Reprod. 49, 1102-1107. 
SAS, 1985. SAS User's Guide: Statistics, fifth ed. Statistical Analysis System Institute Inc., Cary, NC.

SAS, 1992. Changes and Enhancement: Technical Report, SAS/STAT Software.

Savio, J.D., Keenan, L., Boland, M.P., Roche, J.F., 1988. Pattern of growth of dominant follicles during the oestrous cycle of heifers. J. Reprod. Fert. 83, 663-671.

Savio, J.D., Thatcher, W.W., Morris, G.R., Entwistle, K., Drost, M., 1992. Terminal follicular development and fertility in cattle is regulated by concentrations of plasma progesterone. In: Proceedings of the 12th International Congress on Animal Reproduction, The Hague, The Netherlands, vol. 2, pp. 999-1001.

Savio, J.D., Thatcher, W.W., Badinga, L., de la Sota, R.L., Wolfenson, D., 1993. Regualtion of dominant follicle turnover during the oestrous cycle in cows. J. Reprod. Fert. 97, 197-203.

Sirois, J., Fortune, J.E., 1988. Ovarian follicular dynamics during the estrous cycle in heifers monitored by real-time ultrasonography. Biol. Reprod. 39, 308-317.

Sirois, J., Fortune, J.E., 1990. Lengthening the bovine estrous cycle with low levels of exogenous progesterone: a model for studying ovarian follicular dominance. Endocrinology 127, 916-925.

Spicer, L.J., Echternkamp, S.E., 1995. The ovarian insulin and insulin-like growth factor system with an emphasis on domestic animals. Dom. Anim. Endocrinol. 12, 223-245.

Steele, R.G.D., Torrie, J.H., 1980. Principles and Procedures of Statistics. McGraw-Hill, New York.

Stock, A.E., Fortune, J.E., 1993. Ovarian follicular dominance in cattle: relationship between prolonged growth of the ovulatory follicle and endocrine parameters. Endocrinology 132, 1108-1114.

Taylor, C., Rajamahendran, R., Walton, J.S., 1993. Ovarian follicular dynamics and plasma luteinizing hormone concentrations in norgestomet-treated heifers. Anim. Reprod. Sci. 32, 173-184.

Ui, M., Shimonaka, M., Shimasaki, S., Ling, N., 1989. An insulin-like growth factor binding protein in ovarian follicular fluid blocks follicle stimulating hormone steroid production by ovarian granulosa cells. Endocrinology 125, 912-916.

Wehrman, M.E., Roberson, M.S., Cupp, A.S., Kojima, F.N., Stumpf, T.T., Werth, L.A., Wolfe, M.W., Kittok, R.J., Kinder, J.E., 1993. Increasing exogenous progesterone during synchronization of estrus decreases endogenous $17 \beta$-estradiol and increases conception in cows. Biol. Reprod. 49, 214-220.

Wolfe, M.W., Stumpf, T.T., Roberson, M.S., Wolfe, P.L., Kittok, R.J., Kinder, J.E., 1989. Estradiol influences on pattern of gonadotropin secretion in bovine males during the period of changed responses to estradiol feedback in age-matched females. Biol. Reprod. 41, 626-634. 